\title{
A STUDY ON TEACHING APPLICABLE MATHEMATICS IN THE UNIVERSITIES OF NEPAL
}

\author{
Dinesh Panthi*, Ritu Basnet and K. Jha \\ Department of Natural Science (Mathematics) \\ Kathmandu University, P.O. Box 6250, Dhulikhel, Kavre Nepal. \\ *Corresponding E-mail: panthid06@ku.edu.np \\ Received 21 July; Revised 15 September
}

\begin{abstract}
The main objective of this paper is to analyze the program wise weightage of mathematics curriculum in universities of Nepal, in the areas of pure and applied mathematics. It also deals with the status of students' performance for mathematics at various levels.
\end{abstract}

\section{INTRODUCTION}

Most mathematical ideas are the result of intuition. Mathematical sciences have changed significantly during the past few decades. The quantity of new knowledge in mathematics doubled about every decade [11]. Nepalese mathematical system is highly influenced by the mathematical system existing in neighboring countries especially in India. The education, research, studies and training institutions like the schools, the colleges and the universities are the treasure-house of knowledge, skill, and know how which enable our youth to learn the art of living and to serve the nation.

The present higher education system of Nepal has undergone sudden expansion from one to six universities and two autonomous degree awarding institution namely B.P Koirala Institute for Health Science and National Academy of Medical Science in the last decade. The existing six universities in Nepal are Tribhuvan University (TU); Nepal Sanskrit University (NSU); Kathmandu University (KU); Purbanchal University (PbU); Pokhara University (PU) and Lumbini International Buddhist University (LIBU). Each of these institutions has been established by an act of Parliament. Moreover, the growing demand for technical, vocational and professional education, resource constraints with the government and the scope desirability of greater private sector participation are the most pressing issues for the Nepalese education system.

TU was established in 1959 and it stood as the only national institute of higher education in Nepal for many years. This university has a total of 476 colleges. Among them 60 are constituents and 416 are affiliated. TU consists of four faculties: Humanities \& Social Sciences, Management, Education and Law. It has five technical institutes namely Medicine, Engineering, Forestry, Agriculture \& Animal Sciences, Sciences \& Technology. It offers intermediate (I.Ed./ I.A./ I.Sc.), undergraduate (B.Sc./ B.Ed./ B.A.), masters (M.Sc./ M.A./ M.Ed.), and Ph.D. level programs in mathematics.

NSU was established in 1986 (earlier named as Mahendra Sanskrit University).This university has a total of 25 colleges. Among them 12 are constituents and 17 are affiliated. NSU consists of three faculties: Humanities \& Social Sciences, Education \& Ayurvedic. It offers Intermediate (Uttar Madhyama), undergraduate (Shastri/ B.A.), and B.Ed. levels in mathematics. 
KU was established in 1991. has a total of 14 colleges. Among them one is constituent and 13 are affiliated. This university offers its academic programs through six schools: Science, Management, Engineering, Medical Sciences, Arts and Education. The school of science of KU offers M.Phil. and Ph.D programs in mathematics. Also, the School of Education offers Post Graduate Diploma (PGD), M.Ed., M.Phil. and Ph.D. in mathematics education. KU has 13 colleges affiliated to school of medical sciences, school of arts, and school of management.

PbU was established in 1995. This university has a total of 93 colleges. Among them three are constituents and 90 affiliated. PbU consists of four faculties Sciences \& Technology, Management, Arts, and Education. It offers B.Ed. program in mathematics.

PU was established in 1997. This university has a total of 28 colleges. Among them three are constituents and 25 affiliated. PU consists of three faculties: Sciences \& Technology, Management, Humanities \& Social Sciences. It has applied mathematics courses in technical programs.

LIBU was established in 2004. So far it has not started its academic programs.

The following table shows the number of teachers, non-teaching staffs, students and teacher student's ratio in the constituent colleges plus successful graduates from the Nepalese universities in the academic year 2006/ 2007:

Table 1 Universitywise Record of teacher and students

\begin{tabular}{|l|l|l|l|l|l|}
\hline Universities & $\begin{array}{l}\text { No.of } \\
\text { Teachers }\end{array}$ & Number of Non-teaching staf & No. of students & $\begin{array}{l}\text { Teacher-Student's } \\
\text { Ratio }\end{array}$ & $\begin{array}{l}\text { Successful } \\
\text { Graduates }\end{array}$ \\
\hline TU & 6161 & 6072 & 170700 & $1: 28$ & 49375 \\
\hline NSU & 1178 & 406 & 2081 & $1: 2$ & 1913 \\
\hline KU & 333 & 124 & 2671 & $1: 8$ & 1046 \\
\hline PbU & 42 & 102 & 474 & $1: 11$ & 1512 \\
\hline PU & 52 & 84 & 463 & $1: 9$ & 932 \\
\hline
\end{tabular}

\section{MATHEMATICS IN HIGHER SECONDARY EDUCATION}

Higher Secondary Education Board (HSEB) was established in 1989 under the Higher Secondary Education Act of the parliament of Nepal. It is said that education is a life long process, but the basic education that one gets during the formative years definitely contributes to the shaping of one's future and outlook. This is where the school education assumes importance.

The HSEB has been introduced to provide quality education to a larger part of population though out the country. Because of the limited number of universities and campuses and their concentration in the urban and semi urban areas, a large group of students in the rural areas are either deprived of education or are forced to migrate in the urban. Although, the system promotes female participation but a girl has many constraints in the Nepali society and she still 
has to face a lot of problem of leaving home for further studies. In this regard the, Higher Secondary Education Schools established near their home places provide them with the opportunity to be a part of the mainstream [12]. There are 1545 higher secondary school affiliated with HSEB and 114 campuses affiliated with different universities in which the courses of $10+2$ and intermediate are being taught. So all together, there are 1659 institutions offering higher secondary level education and this number is increasing annually.

Now we present year wise final examination results of HSEB and that of KU that shows the performance of the boys and girls in the mathematics. In case of HSEB, mathematics course is compulsory in the first year and students have a mathematics course as an elective in second year. There is a special mathematics course for management and engineering students at this level. The following table shows the number of boys and girls who appeared and passed 10+2 of HSEB for the last five years:

Table 2. HSEB XII Results

\begin{tabular}{|l|l|l|l|l|l|l|}
\hline Year & \multicolumn{4}{|l|}{ Appeared } & \multicolumn{3}{l|}{ Passed } & \\
\hline & Boys & Girls & Total & Boys & Girls & Total \\
\hline 2002 & 4847 & 1382 & 6229 & 1821 & 1022 & 2843 \\
\hline 2003 & 5117 & 1366 & 6483 & 2946 & 695 & 3641 \\
\hline 2004 & 6982 & 1903 & 8885 & 3392 & 790 & 4182 \\
\hline 2005 & 7965 & 2102 & 10067 & 5121 & 1214 & 6335 \\
\hline 2006 & 10721 & 2893 & 13614 & 6963 & 2817 & 9780 \\
\hline
\end{tabular}

Source: Examination Section, HSEB, Sanothimi, 2006

\section{Graphical Representation}

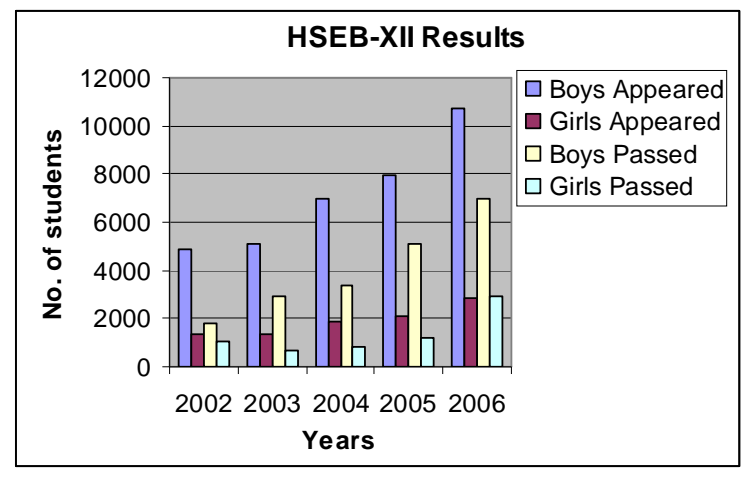

The graph above shows that the number of the boys and girls appearing in the successive years from 2002 to 2006 is increasing whereas the number of female students in the year 2003 is comparatively less. Looking at the results for these years the average pass percentage of students is about 59\%. Among which the average pass percentage of boys is about $55 \%$ and that of girls is about $64 \%$. We can say that the interest of the students in mathematics is increasing which is positive sign and inspiring sign for mathematics education in Nepal. The following graph shows the dropout percentage at HSEB examination for the last five years: 


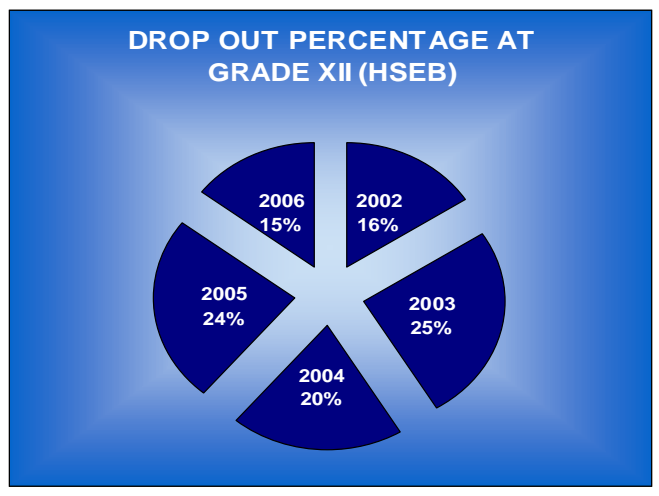

The chart above shows that the dropout rate on the average is about $20 \%$, which is very high at intermediate level.

In case of $\mathbf{K U}$, mathematics course is compulsory for both first and second year students at $\mathbf{I}$. Sc. level. The following graph shows the year wise number of boys and girls who appeared and passed I. Sc. program of KU for the last five years:

Table 3. KU (I. Sc.) Results

\begin{tabular}{|l|l|l|l|l|l|l|}
\hline Year & \multicolumn{4}{|l|}{ Appeared } & \multicolumn{3}{l|}{ Passed } \\
\hline & Boys & Girls & Total & Boys & Girls & Total \\
\hline 2002 & 182 & 51 & 233 & 166 & 49 & 215 \\
\hline 2003 & 216 & 78 & 294 & 183 & 64 & 247 \\
\hline 2004 & 143 & 63 & 206 & 132 & 61 & 193 \\
\hline 2005 & 153 & 68 & 221 & 138 & 65 & 203 \\
\hline 2006 & 118 & 57 & 175 & 61 & 39 & 100 \\
\hline
\end{tabular}

Source: Examination Section, KU, 2006

\section{Graphical Representation}

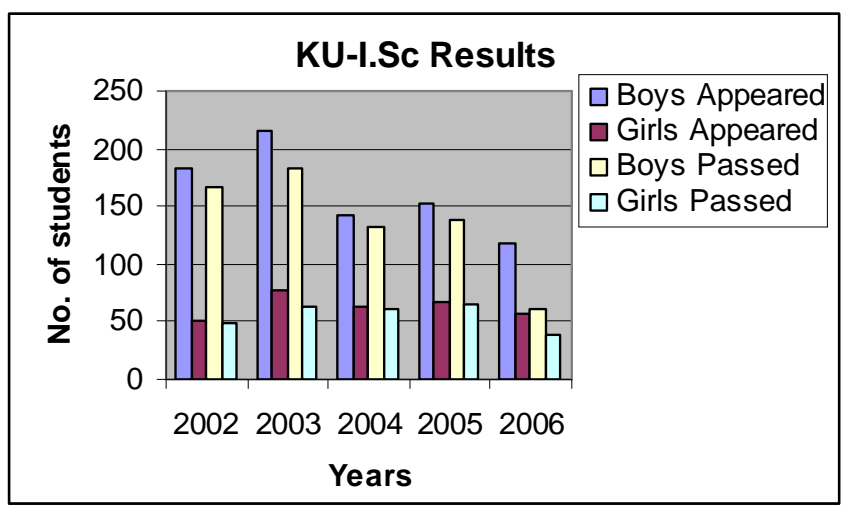

The graph above shows that the number of students is decreasing from 2002 to 2006. This is due to the policy of the university to phase out I.Sc. Program. Looking at the results for these years, the average pass percentage of students is about $85 \%$. Among which the average pass 
percentage of boys is about $83 \%$ and that of girls is about $87 \%$, which is comparatively high and encouraging.

\section{MATHEMATICS AT BACHELOR LEVEL}

Depending on the objectives and scopes of different Bachelor Level programs, various mathematics courses are taught in Nepal. There are both pure and applied mathematics courses at bachelor level program. Pure mathematics is generally done for its own sake, whereas "applied" mathematics is to impart skill to solve a real world problem. Real world problems often lead to new mathematical ideas that develop new branches independent of the original applications. Mathematics originally done for its own sake often finds unexpected applications afterwards. Pure mathematics involves systematic and deductive reasoning. But any applied mathematics course depends on pure mathematics courses taught earliar.

Now, we analyze the programwise weightage of mathematics curriculum in different universities of Nepal, in term of pure and applied mathematics.

\section{Weightage of Pure mathematics courses at different programs}

Table 4. Universitywise Weightage of Pure Mathematics

\begin{tabular}{|c|c|c|c|c|c|c|c|c|}
\hline \multirow[t]{2}{*}{ Uni. } & \multirow[t]{2}{*}{$\begin{array}{l}\text { B. Ed. } \\
\text { (3Years) } \\
\text { Total Marks }\end{array}$} & \multicolumn{2}{|c|}{$\begin{array}{l}\text { Weightage for } \\
\text { Mathematics } \\
\text { Courses }\end{array}$} & \multirow[t]{2}{*}{$\%$} & \multirow[t]{2}{*}{$\begin{array}{l}\text { B. Sc./ B. A. } \\
\text { (3 Years) } \\
\text { Total Marks }\end{array}$} & \multicolumn{2}{|c|}{$\begin{array}{ll}\text { Weightage for } \\
\text { Mathematics } \\
\text { Courses }\end{array}$} & \multirow[t]{2}{*}{$\%$} \\
\hline & & Pure & Applied & & & Pure & Applied & \\
\hline TU & 1500 & 400 & 200 & 40.00 & 1400 & 400 & 200 & 42.85 \\
\hline NSU & - & - & - & - & 1400 & 400 & 200 & 42.85 \\
\hline
\end{tabular}

Pure mathematics is generally taught at Bachelor (B.A. / B.Sc. / B.Ed.) and master (M.A. / M.Sc. / M.Ed.) level programs. In average, the weightage of Mathematics at Bachelor level is found to be about $41 \%$ for mathematics major students.

Weightage of Applied mathematics courses at different programs

Table 5. Universitywise Weightage of Applied Mathematics

\begin{tabular}{|l|l|l|l|l|l|l|}
\hline Uni. & $\begin{array}{l}\text { B.E. and } \\
\text { Comp. Sc., } \\
\text { Total Credit }\end{array}$ & $\begin{array}{l}\text { Maths } \\
\text { Credit }\end{array}$ & $\%$ & $\begin{array}{l}\text { B.E. } \\
\text { Electronic } \\
\text { Engg., } \\
\text { Total Credit }\end{array}$ & $\begin{array}{l}\text { Maths } \\
\text { Credit }\end{array}$ & $\%$ \\
\hline TU & 152 & 21 & 13.81 & 140 & 20 & 14.28 \\
\hline KU & 149 & 20 & 13.42 & 150 & 17 & 11.33 \\
\hline PbU & 170 & 18 & 10.58 & 160 & 22 & 13.75 \\
\hline PU & 126 & 21 & 16.66 & 125 & 21 & 16.80 \\
\hline
\end{tabular}


Table 6. University wise Weightage of Applied Mathematics

\begin{tabular}{|l|l|l|l|l|l|l|}
\hline Uni. & $\begin{array}{l}\text { B.E. } \\
\text { Electrical } \\
\text { Engg., } \\
\text { Total credit }\end{array}$ & $\begin{array}{l}\text { Credits } \\
\text { for } \\
\text { Maths }\end{array}$ & $\%$ & $\begin{array}{l}\text { B.E. } \\
\text { Civil Engg., } \\
\text { Total Credit }\end{array}$ & $\begin{array}{l}\text { Credits } \\
\text { for } \\
\text { Maths }\end{array}$ & $\%$ \\
\hline TU & 150 & 21 & 14.00 & 149.5 & 21 & 14.04 \\
\hline KU & 150 & 17 & 11.33 & - & - & - \\
\hline PbU & - & - & - & 194 & 22 & 11.34 \\
\hline PU & 129 & 21 & 16.27 & 125 & 18 & 14.40 \\
\hline
\end{tabular}

All programs mentioned above are technical where applied mathematics is taught. The weightage of each mathematics course in any level is based on the credits given for it. On average, the credit for mathematics given by the universities in Nepal is found to be around 20 credits in the whole curriculum. Some of the other programs where mathematics is applicable are Bachelor of Information Technology Engineering, Bachelor of Mechanical Engineering, Bachelor of Business Information System, Bachelor of Environmental Science, Bachelor of Hotel Management, Bachelor of Software Engineering, Bachelor of Environmental Engineering, Bachelor of Business Administration, Bachelor of Business Studies, Bachelor of Travel and Tourism Management etc.

\section{PERFORMANCE OF STUDENTS AT MASTER'S LEVEL}

TU offers master (M. A./ M. Sc.) program in mathematics. Also, TU started its M. Ed. program in 1976 and KU has recently launched M. Ed. program in 2006.

Table 7. Universitywise Weightage of Mathematics

\begin{tabular}{|l|l|l|l|l|l|l|}
\hline Uni. & $\begin{array}{c}\text { M.Ed. } \\
\text { Total Marks }\end{array}$ & $\begin{array}{l}\text { Weightage } \\
\text { Maths }\end{array}$ & $\%$ & $\begin{array}{l}\text { M.A./ M.Sc. } \\
\text { Total Marks }\end{array}$ & $\begin{array}{l}\text { Weightage } \\
\text { Maths }\end{array}$ & $\%$ \\
\hline TU & 1000 & 500 & 50 & 1000 & 1000 & 100 \\
\hline KU & 1000 & 700 & 70 & - & - & - \\
\hline
\end{tabular}

The following table shows the number of male and female students who appeared and passed M.A./ M.Sc. for the last five years from TU: 
Table 8. M. A./ M. Sc. Results of TU

\begin{tabular}{|l|l|l|l|l|l|l|}
\hline Year & \multicolumn{4}{|l|}{ Appeared } & \multicolumn{3}{l|}{ Passed } \\
\hline & Male & Female & Total & Male & Female & Total \\
\hline 2002 & 140 & 13 & 153 & 16 & 0 & 16 \\
\hline 2003 & 211 & 12 & 223 & 37 & 2 & 39 \\
\hline 2004 & 277 & 14 & 291 & 53 & 2 & 55 \\
\hline 2005 & 302 & 16 & 318 & 71 & 5 & 76 \\
\hline 2006 & 318 & 10 & 328 & 101 & 2 & 103 \\
\hline
\end{tabular}

Source: Dean's office, Institute of Science, TU.

\section{Graphical Representation}

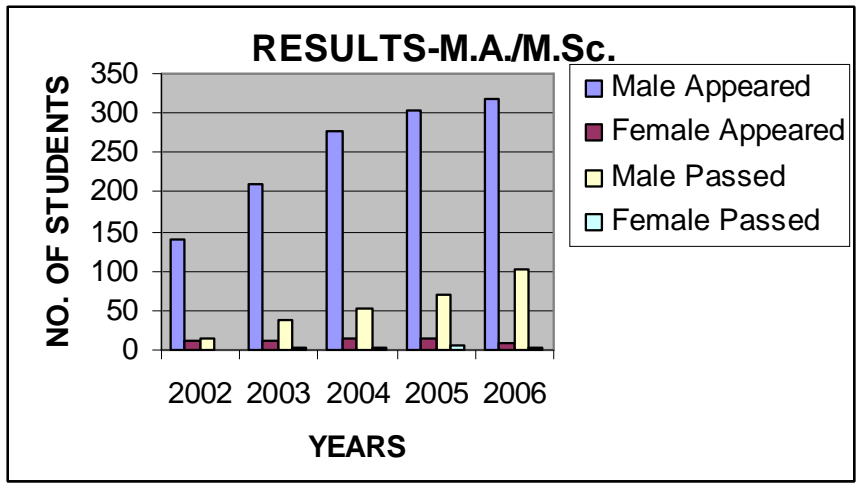

The following table shows the number of students who appeared and passed M. Ed. from TU.

Table 9. M. Ed. Results of TU

\begin{tabular}{|l|l|l|}
\hline Year & Appeared & Passed \\
\hline 2002 & 66 & 5 \\
\hline 2003 & 96 & 1 \\
\hline 2004 & 102 & 10 \\
\hline 2005 & 152 & 66 \\
\hline 2006 & 179 & 62 \\
\hline
\end{tabular}

Source: Offices of the Controller of Examination,TU. 


\section{Graphical Representation}

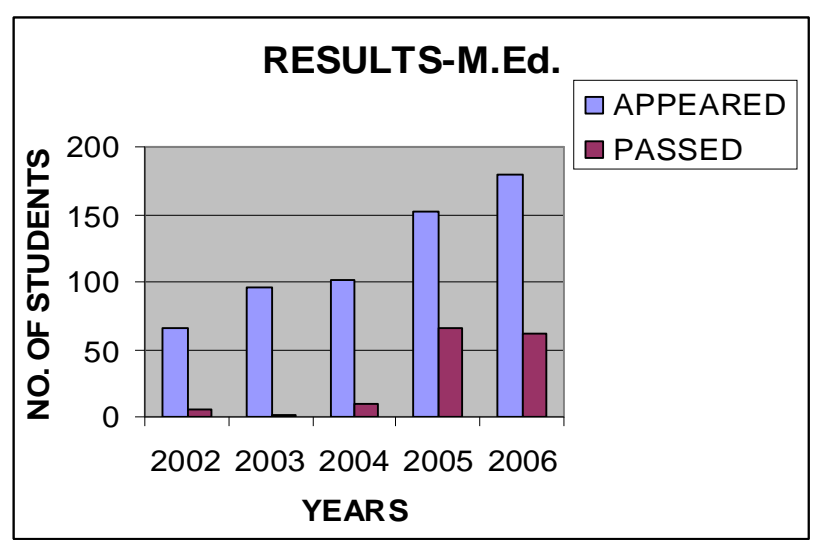

Above two charts related to M. A/ M. Sc. and M. Ed. programs show that the number of the female graduates is very low compared to the number of male students. There are very few female mathematicians in Nepal.

\section{CONCLUSIONS}

This paper has mainly focused on the weightage of mathematics in terms of pure and applied fields. For this purpose, Science, Arts, Education and Engineering programs of Bachelor level were considered. The results of students in Master level of Arts, Science and Education were taken into consideration. The study briefly shows that the enrollment of students in mathematics at intermediate level is satisfactory but the pass percentage is comparatively less. Also, the weightage for mathematics given by $\mathbf{K U}$ at intermediate level (I. Sc.) is comparatively better. The average passed percentage of girls is better than that of boys. The number of dropout students in mathematics at HSEB level is significantly high. Again, the credit systems of different universities regarding mathematics courses vary significantly in different programs. Moreover, the female enrollment at master level was found to be very poor and the passed percentage of the students is disappointing. But there is the chance of improvement for better outputs.

\section{REFERENCES}

1. Tuladhar, B. and K. Jha 2002. A brief report on mathematics education in Nepal, Ganita Bharathi, vol.24, No. 1- 4.

2. Jha, K. 2005. Mathematics Teaching for IT in Universities of Nepal, Shiksha Shastra Saurabh, vol. 11, No. $61-68$.

3. Annual report 1999 -2007. University Grants Commission, Sanothimi, Bhaktapur, Nepal.

4. Bachelor's Course Catalogue 1999. Tribhuvan University, Kirtipur, Kathmandu, Nepal.

5. Programme Catalogue 2006. Pokhara University, Pokhara, Kaski, Nepal. 
6. Programme Catalogue 2006. Purbanchal University, Biratnagar, Morang, Nepal.

7. Programme Catalogue 2006. Nepal Sanskrit University, Dang, Nepal.

8. Programme Catalogue 2007. Kathmandu University, Dhulikhel, Kavre, Nepal.

9. Annual Report 2007. Controller of Examination, Higher Secondary Education Board, Sanothimi, Bhaktapur, Nepal.

10. Pant, S.R. and D.B. Adhikari 2001. Relevance of Undergraduate and Graduate Level Mathematics Curriculum in the Universities of Nepal and Problems in its Implementation, a paper presented at the National Seminar on Mathematics in Kathmandu during Feb.9 -10,

11. Steen L.A. 1978. Mathematics Tomorrow, Springer -Verlag, NewYork.

12. website: www.hseb.edu.np

13. website: www.nast.org.np 